\title{
Ortodokse fundamentalisme en die gebruik van die Ou Testament in Suid-Afrika
}

\author{
J A LOADER
}

In verskeie godsdienste kom die verskynsel voor wat ons fundamentalisme kan noem, byvoorbeeld in die Judaïsme en die Islam. In hierdie artikel gaan dit my egter alleen om die fundamentalisme binne die Christendom, en dan spesifiek dié sektor van die Christendom waarbinne ons met ons reformatoriese belydenis en teologiese tradisie staan. Dus sluit ek in my bespreking die fundamentalistiese tendense binne die Rooms-Katolieke teologie en die bekende fundamentalisme van die sektariese groeperinge uit. Hoewel daar besliste historiese verbande bestaan tussen die fundamentalisme van die Gereformeerde tradisie in Nederland en dié in die reformatories-gereformeerde tradisie van die Afrikaanse kerke, sal 'n bespreking van die ontwikkelinge in Nederland sowel as in Suid-Afrika die grense van 'n artikel by verre oorskry. So fokus ek die aandag (behalwe vir enkele verwysings) op die Afrikaanse kerklike wêreld omdat dit ons direk raak.

Met "ortodokse fundamentalisme" word dan alleen bedoel die fundamentalistiese tendense en invloed binne die reformatoriese (of gereformeerde) teologiese wêreld van Suid-Afrika. Die uitdrukking suggereer dus nie dat ons moet onderskei tussen 'n suiwer ortodokse soort fundamentalisme en ' $n$ heterodokse fundamentalisme wat afwykend van die hooflyn van die fundamentalisme sou wees nie. Soos ek sal aandui, is daar wel verskeie modaliteite binne die fundamentalistiese invloedsfeer teenwoordig, maar die basiese grondprobleme van die fundamentalisme kom in almal voor. "Ortodokse fundamentalisme" suggereer ook nie dat daar 'n noodwendige verband bestaan tussen die geloofsoortuigings van die ortodokse reformatoriese belydenis en die fundamentalisme nie. Inteendeel, dit is nie alleen moontlik nie, maar myns insiens noodsaaklik dat 'n ortodokse belydenis gehandhaaf word sonder affiliasie met die fundamentalisme of (op verskillende wyse) met die fundamentalistiese idioom.

James Barr ${ }^{1}$ meen dat dit die beste is om 'n oorvereenvoudigde definisie van wat fundamentalisme is, te vermy en liewer die basiese kenmerke van die fundamentalisme te gebruik as vertrekpunt vir 'n omvangryke beskrywing van die verskynsel in al sy geledinge. Dit kom my aanvaarbaar voor, want so sal ons in die literatuur self kan 
toets of ons met fundamentalisme en fundamentalistiese invloed te doen het en hoe dit die gebruik van die Bybel raak. Die drie vernaamste kenmerke wat Barr in die Brits-Amerikaanse fundamentalisme vind, is die volgende: (1) Sterk klem op die onfeilbaarheid van die Bybel as Gods woord. Dit word met die inspirasieleer verbind en só verstaan dat enige soort "fout" in die Bybel ontbreek. (2) 'n Vyandigheid teen die moderne kritiese studie van die Bybel. (3) ' $n$ Houding dat andersdenkendes afvallige Christene is, nie vertrou kan word nie en 'n gevaar inhou vir die ware geloof (met "andersdenkendes" word dan bedoel diegene wat die moderne Bybelwetenskap beoefen). Dit is opvallend dat die debatte binne hierdie veld meer konsentreer op die Ou Testament as op die Nuwe, hoewel die Nuwe-Testamentiese terrein natuurlik glad nie vry is van fundamentalisme nie. ' $n$ Rede hiervoor is waarskynlik dat die onfeilbaarheid van die Bybel (soos die fundamentalisme dit verstaan) gekoppel word aan die inspirasieleer (weer: soos die fundamentalisme dit verstaan), en dit werk die maklikste wanneer mens te doen het met duidelik omlynbare figure wat as skrywers van die Bybel kan geld. Hierdie outeurskapsidee is veel moeiliker om staande te hou in die Ou-Testamantiese as in die Nuwe-Testamentiese tekste en daarom is dit natuurlik dat die Ou Testament 'n brandpunt van aandag sal wees. Hiermee is dan ook ' $n$ vooropstaande debatsterrein aangedui: Die outeurskapsidee bekom 'n sleutelposisie in die fundamentalistiese denke. ' $n$ Ander rede vir die prominensie van die Ou Testament is waarskynlik dat historiese probleme in die Ou Testament meer akuut aangevoel word as dié in die Nuwe Testament. Daarmee is nog ' $n$ belangrike debatsterrein gegee: Die historiese vrae rondom die Ou Testament word 'n dominante posisie toegeken. Nie werklik die vraag "Wie es nun eigentlich gewesen ist" nie, maar die verdediging "dass es eigentlich so gewesen ist". 'n Derde rede wat hiermee verband hou, is waarskynlik dat die aard van die Ou Testament, met sulke temas soos skepping en sondvloed en sulke literatuursoorte soos wonderverhale en geskiedskrywing, die fundamentalisme dwing om baie swaar op hierdie onderwerpe te konsentreer.

Naas die totale fundamentalisme onderskei Barr' ook nog ' $n$ tendens wat 'n "maximal conservative" standpunt genoem word. Daarmee bedoel hy ' $n$ standpunt "that uses the maximal conservative argument on historical issues", en voeg by ". . this material will naturally be read by fundamentalists as if it completely favoured the most highly conservative historical possibilities, but if read in another way it manifestly leaves open the line of retreat towards a more critical position, which is 'less probable' ..." (p 126). Barr gebruik die term "conservative" nie met die konnotasies wat ons daaraan heg nie, maar as aanduiding van die algemene standpunt waarvan BritsAmerikaanse fundamentaliste gewoonlik sê dat hulle voorstanders 
is. Dit gaan hier dus om teoloë wat nie uitgesproke fundamentaliste is nie, maar wat op dié punte wat vir die fundamentalisme so belangrik is, ' $n$ posisie inneem wat dit vir die fundamentalisme moontlik maak om homself te handhaaf en wat daarom binne die ban van die fundamentalisme bly en dit selfs voed - sonder om "intellectual respectability" (Barr se uitdrukking) prys te gee.

Die implikasies van fundamentalisme en dit wat die fundamentalisme help voortplant, is ingrypend. Behalwe dat die aandag buite verhouding toegespits word op bepaalde tekste, probleme en temas ten koste van andere, maak dit ook die werklike vrugte van die kritiese Bybelwetenskap onbruikbaar. 'n Bepaalde raamwerk word geskep waarbinne die hele Ou Testament verstaan moet word - waardeur alle ander moontlikhede afgesny word al kan sulke nie-fundamentalistiese resultate ook ' $n$ verryking meebring in ons verstaan van die Ou-Testamentiese prediking sonder dat die ortodoksie daardeur in gevaar kom. Byvoorbeeld: Die Esterverhaal moet geskiedenis wees. Dit word bloot aanvaar sonder besinning oor die vraag waarom daar nie ook in die Ou Testament predikende verhale kan wees soos in die Nuwe Testament nie en waarom sulke verhale nie ook in boekvorm kan bestaan sonder om in die mond van ' $n$ historiese figuur gelê te word nie. So word dit eenvoudig onmoontlik gemaak om die kragtige boodskap van die boek in te sien. Al wat teen 'n literêrkritiese resultaat (dat die boek gaan oor Gods ingrype in die lewe en die verhouding daarvan tot menslike verantwoordelikheid) gesê kan word, is dat die boek in die Bybel staan en daarom een of ander historiese boodskap moet hê. Dié deklarasie kan gemaak word, maar nie onderbou word nie en kan dus ook nie 'n kritiese vraesteller bevredig nie.

II

Vervolgens wil ek graag aandag gee aan die Afrikaanse literatuur wat vir ons onderwerp van belang is. Daar is so baie wat aangehaal kan word dat ek uiteraard 'n keuse moes maak. Ek het my daarby laat lei deur die prinsipe om so verteenwoordigend as moontlik te wees en om te konsentreer op die invloedrykste gevalle.

Een van die invloedrykste figure op hierdie gebied is die groot Afrikaner J D du Toit ${ }^{3}$. Sy gees deurtrek nie alleen die huidige Afrikaanse Bybelvertaling nie, maar die kragveld van sy sienswyses werk tot vandag toe nog deur - soos ek sal probeer aandui. Die eerste wat die leser van sy talle artikels en voordragte opval, is die presiese ooreenkoms met die kenmerke van die algemene fundamentalisme: 'n Verdediging van sý idee van die onfeilbaarheid van die Bybel, 'n felle vyandigheid teen die kritiese Bybelwetenskap, en 'n veroordeling van teengestelde menings as afvalligheid en valsheid. Die aan- 
halings hieronder is uit Versamelde werke van J $D$ du Toit (Totius), Johannesburg 1960-1961, verskillende dele. "Die ortodokse geleerde beoefen nie die inleidingswetenskap (kanoniek) om daarmee, in hoe geringe mate ook, aan die Skrifkritiek deel te neem nie. Nee, hy moet kennis neem van die metode en resultate van die Skrifkritiek maar alleen om dit te bestry" (IV, p 293). "Wie volgens ons Belydenis die Skrifgesag ten volle aanvaar, kan met die Skrifkritiek geen enkele skrede saamgaan nie" (IV, p 294). Hy maak die vroomklinkende uitspraak "dat die Skrif my moet kritiseer, en nie ek die Skrif nie" (IV, p 279), waardeur hy toon dat hy nie begryp dat die term "kritiek" in die wetenskap niks te doen het met die tug van Gods woord nie, maar alleen die wetenskaplike analise van die Bybel aandui. Wanneer ' $n$ mens nie hiermee saamgaan nie, beskuldig Totius hom van "ongeloof, puur en simpel" (IV, p 275), met die noodwendige konsekwensie van "Skrifverwerping en Christus-versaking" (IV, p 265). Totius doen baie moeite om sý idee van die onfeilbaarheid van die Bybel te verdedig, want as daar ' $n$ vergissing in die Bybel sou wees, dan word God 'n leuenaar omdat Hy ons dan 'n Bybel sou gegee het waarin allerlei onwaarhede voorkom (IV, p 277, waar Totius met instemming aanleun by $\mathrm{H} \mathrm{H}$ Kuyper). Dit is ook onaanvaarbaar om te sê dat die Bybel "aan ons gegee is tot saligheid en nie om op onfeilbare wyse allerhande historiese of oudheidkundige besonderhede aan ons bekend te maak nie" (IV, p 289). Volgens Totius is dit 'n blote uitvlug. So het Moses volgens hom die hele Pentateuch (behalwe die laaste hoofstuk) bemiddel en selfs persoonlik "die hele wetgewing op skrif gestel" (IV, p 284). As iemand vir hom sou sê dat Levitikus nie deur Moses geskryf is nie, sal hy "so iemand met alle krag teëstaan" (IV, p 283). As die Ou Testament sê dat iets plaasgevind het, is dit werklike geskiedskrywing, naamlik "die beskrywing van wat werklik gebeur het" (IV, p 263). Die finale bewys hiervoor is dat die Skrif volgens hom self so sê. Daarom is die bronnesplitsing in die Pentateuch belaglik en vyandskap teen die Woord (Vergelyk IV, pp 287ff).

Hierdie onwetenskaplike rigorisme verg inkonsekwensies van Totius waaruit hy nie kan loskom nie. Die skeppingsverhaal is 'n "historiese berig omtrent die skeppingsfeite" (IV, p 302). "Die enigste veilige uitgangspunt is dat ons aanneem dat daar géén tweestryd kan bestaan tussen die feite wat God in sy Woord openbaar, en dié wat in die natuur waargeneem kan word nie" (IV, p 303). Die ses skeppingsdae is letterlik dae (IV, pp 307-309). Die poging om die Bybel te rym met die geologiese wetenskap deur die dae as tydperke te vertolk, is onaanvaarbaar. Hulle kon wel volgens Totius buitengewone dae gewees het omdat God buitengewoon is, maar nogtans bly hulle letterlik dae - dus gewone dae. Buitengewone gewone dae! Die evolusieteorie is onaanvaarbaar (VI, pp 241ff) omdat die Bybel letterlik 
sê dat God alles, die mens inkluis, volgens hulle soorte gemaak het. Wat die ouderdom van die aarde betref, "soek en tas" die geologie teenoor die Bybel wat "onveranderlik is en bly tot in ewigheid" (Vl, $\mathrm{p}$ 246). Al gee Totius toe dat die wetenskap ruimte het, is die minimalisering van die wetenskap hier onmiskenbaar. Maar op bepaalde punte word dit onhoudbaar en moet Totius omspring. Hy weet dat die "voor-Ptolemeïese wêreldbeeld" nie korrek is nie, want die natuurwetenskap het bewys dat die aarde rond is en om die son draai. Daarom is dit onmoontlik dat die Bybel met so 'n onwetenskaplike wêreldbeeld kan werk, want dan sou God' $n$ fout gemaak het deurdat die inspirasie van die Heilige Gees verkeerde inligting verstrek het. Die gevolg is dat hy die Bybelse uitsprake oor die hemelliggame (byvoorbeeld in Gen 1) moet forseer om in te pas by die moderne wetenskaplike wêreldbeeld (IV, p 298). Nou "soek en tas" die wetenskap nie meer nie, maar die getuienis daarvan is so oorweldigend dat Totius die Bybel onder die dwang van die wisselende en onbetroubare menslike wetenskap moet interpreteer. Dus word die letterlike interpretasie waarop hy so gesteld is, oorboord gegooi wanneer dit hom nie pas nie. Hierdie inkonsekwente handhawing en verwerping van letterlike interpretasie, gepaard met 'n inkonsekwente onafhanklikheid en áfhanklikheid van die natuurwetenskap is tipies van die wêreldfundamentalisme ${ }^{4}$.

Totius word ook om ' $\mathrm{n}$ ander rede gedwing om sy letterlike voorkeure te verwater. 'n Goeie voorbeeld hiervan is sy behandeling van Jefta se dogter (IV, pp 316-320). In Rigt. 11 vind hy getuienis dat Jefta 'n goeie gelowige was. Nou is mense-offers deur die wet verbied (Lev 20:2-5 en ander). Daarom kon 'n gelowige soos Jefta nie sy dogter geoffer het nie: Al staan daar dat hy haar as brandoffer geoffer het, kan dié woord volgens Totius nie letterlik "offer" beteken nie en moet dit iets anders wees - sonder dat die literêre kwaliteit van die verhaal enigsins iets mee te spreek het.

Hoewel die waarheid van die Bybel nie deur argeologiese ontdekkings bewys kan word nie, maak Totius nogtans graag gebruik van sulke gegewens om "die glorie van die Bybel" te handhaaf (IV, pp 312-315). Hierdie liefde vir argeologiese bondgenote teen die kritese wetenskap (op gepaste oomblikke) is ook tipies van die wêreldfundamentalisme ${ }^{5}$. Dit is ook op Afrikaanse bodem in die kragveld van Totius verder gevoer, soos ons hieronder sal sien.

Hierdie voorbeelde uit Totius se werke toon dat hy uit-en-uit 'n fundamentalis was. Ek meen dat ons hier die vinger het op die polsslag van die verskerpte fundamentalisme wat volgens $\mathrm{C} H$ Rautenbach $^{6}$ ná die Geelkerkensaak van Assen 1924-1926 in Suid-Afrika ingetree het. Volgens hom het die Hervormde opleiding nie hierin gedeel nie "want hy kon nie daarmee saamgaan nie." Ek dink 'n verdere proef van die Afrikaanse literatuur sal aandui dat die Totiaanse 
fundamentalisme geensins uitgedien is nie en dat die invloedsfeer wat hierdie denkwêreld opgebou het, nog steeds gevoed word deur fundamentalisme in hedendaagse klere en ook leefruimte gegee word deur "maximal conservatism". Dit ten spyte van die Hervormde anti-fundamentalisme.

Ons kan hierdie proef begin met 'n aantal voorbeelde uit die Afrikaanse Bybel met Verklarende Aantekeninge. Dit is 'n kommentaarwerk wat op alle terreine van die kerklike lewe, veral onder die gewone lidmate, 'n belangrike rol speel en daarom baie invloedryk is. Die bydraes kom van medewerkers uit aldrie kerke en die klemtone wissel dan ook soos mens kan verwag. Nêrens kon ek die skerp polemiese toon van Totiaanse fundamentalisme kry nie, maar sy gees is wel teenwoordig - ò in die vorm van 'n nuutgeklede fundamentalisme, ò só dat die invloedsfeer van die fundamentalisme (ten minste) nie gefrustreer word nie.

S J du Plessis skryf in die inleidings tot Exodus en Levitikus "dat Moses die skrywer kan wees". Hy formuleer dus nie so eksplisiet en polemies soos Totius nie, maar dit is nou juis die interessante punt. Du Plessis verwys na teksverse wat praat van skrywerswerk wat deur Moses gedoen is en bied so hierdie Bybelse uitsprake aan as argumente vir die Mosaïse outeurskap. Hy laat egter die wetenskaplike bewyse dat Moses hoegenaamd nie die skrywer kan wees nie, buite bespreking en suggereer slegs dat hy àl die literêr-kritiese probleme in sy oordeel verwerk het. So moet die leser konkludeer dat daar geen noemenswaardige kwaliteite in die wetenskaplike benadering lê nie en boonop dat Du Plessis se standpunt wetenskaplik is. Die leser word hierdeur gesterk in die populêre opvatting oor die Mosaïese outeurskap. In plaas van 'n uitgesproke vyandskap teen die kritiese wetenskap vind ons hier dan 'n implisiete vyandskap waardeur die resultate van die wetenskap eenvoudig geïgnoreer word. Terselfdertyd oortuig hy die goedgelowige leser dat hy 'n werklike geleerde is ${ }^{7}$. J H Kroeze doen dieselfde met Deuteronomium. Die Mosaïese outeurskap word ook volgehou met verwysing na die feit dat bepaalde tekste (na bewering) self so sê (die "selfgetuienis" wat vir Totius ook belangrik was). Net soos Totius sonder Kroeze die laaste hoofstuk uit en doen moeite om te sorg dat niemand miskien aflei dat dié deel ongeïnspireerd is nie. So stap hy eenvoudig oor die magdom verantwoorde literatuur in verband met die ontstaansgeskiedenis in die latere Deuteronomiese kringe. Hierdie werkswyse sonder die outeurskapskwessie byna as 'n geloofsartikel uit en verteken so die aandag wat dit om 'n ander rede verdien. Die outeurskap is nie in sigself as geloofsaak belangrik nie (soos fundamentaliste self oor anonieme Bybelboeke moet sê), maar wel sover as die onkritiese standpunt alle verdere wetenskaplike ondersoek afsny oor bronne, 
literatuursoorte en tradisies. En dié werp weer lig op tekstuele spanninge, betekenis en draagkrag.

Van die boek Jesaja vermeld P A Verhoef dat sommige verklaarders Jes. 40-66 aan "'n profeet" uit die tyd van die ballingskap toeskryf. Hy formuleer so versigtig dat die leser nie anders kan nie as om af te lei dat hierdie teorie oor die outeurskap (wat Verhoef bowendien simplisties en selfs foutief weergee) onaanvaarbaar is. Dit is ook die eenvoudige veronderstelling waarvan Totius uitgegaan het (IV, p 359). So versterk hy weer die fundamentalistiese leser en verhinder hy die kritiese wetenskap om sy geweldige bydrae oor literêre vorme, tradisies en betekenis van die laaste helfte van die boek te lewer. S du Toit sê in die Daniël-inleiding sonder meer dat die "betroubaarheid" en "historiese geloofwaardigheid" van die boek duidelik bewys is (wat onwaar is omdat daar talle historiese onjuisthede in die boek voorkom). Hy sê hy skryf sy kommentaar vanuit die veronderstelling dat ons hier met werklike geskiedskrywing te doen het (wat geen rekening hou met die feit dat ons hier die genre van die hofverhaal vind waarin motiewe en temas uit die apokaliptiese tradisie verwerk is nie). So lei hy die leser om "betroubaarheid" met historiese juistheid te identifiseer. Daarom mag daar geen onjuistheid in die boek wees nie - 'n fundamentalistiese grondtese (wat nie kan verklaar waarom daar wel verhale van wat nie gebeur het in die Nuwe Testament mag voorkom maar nie in die Ou Testament nie). Ook hy laat die leser dink dat die "Skrifgetuienis" self aan sy kant is teenóór die kritiese wetenskap.

Oor Jona sê T F J Dreyer dat dit 'n werklike historiese gebeurtenis beskryf. Sy "bewyse" kom uit II Konings 14:25 waar van 'n profeet met dieselfde naam gepraat word (die argument van die "Skrifgetuienis"), uit die evangelies waaruit afgelei word dat Jesus die boek as histories aanvaar het ('n tipies fundamentalistiese redenasie wat Totius, IV, p 265, ook gebruik het maar wat geen rekening hou met die feit dat Jesus en die Nuwe Testament hul aangesluit het by die gangbare voorwetenskaplike opvattings van hul tyd nie), en uit ' $n$ beroep op Gods almag waardeur dit moontlik is dat God wel 'n vis kon beskik om Jona in te sluk en uit te spoeg (weer 'n tipiese argument van die fundamentalisme). In die inleiding tot Ester sê $J P$ Oberholzer dat die betekenis van die boek daarin geleë is "dat dit ons 'n stuk geskiedenis bied, wat ons nie uit ander bronne bekend is nie, van die Joodse volk". Dit bring die leser dadelik onder die indruk dat ons hier te doen het met berigte aangaande iets wat werklik, soos beskryf, gebeur het. Indien iemand (wat onwaarskynlik is) die inleiding opvat as bedoelende dat ' $n$ historiese werklikheid beskryf word deur middel van ' $n$ fiktiewe verhaal, word dit vir hom onmoontlik om so te blý dink wanneer hy byvoorbeeld by 9:20-32 kom. Daar ag die kommentator dit waarskynlik dat Mordagai self die 
grootste deel van die boek geskrywe het of minstens iemand wat insig gehad het in sy amptelike kroniek. Dus word aangeneem dat die kenmerke van 'n novelle (byvoorbeeld literêr-gemotiveerde ontwikkeling, konstruksie van spanning, alliterasie in persoonsname) en die historiese onjuisthede insake die gemalin van die koning en sy dekreet van geen belang is nie.

Hierdie aantal voorbeelde, gekies omdat hulle toetspunte is waarop die fundamentalisme baie gesteld is, toon verskillende grade van variasie ten opsigte van die Totiaanse standpunt. Soms kom gewone fundamentalisme voor en soms nie (vergelyk byvoorbeeld die laaste twee gevalle waar die medewerkers Hervormers is). Waar Totius polemies teen die toegewing van enige onjuisthede tevelde getrek het, word hier op sy minste met optimale versigtigheid sorg gedra dat dié "probleme" nie by die leser opkom nie. Soos so tipies van die fundamentalisme, word die vrae oor outeurskap, historisiteit en faktiese korrektheid van die Bybel hier met groot sorg gehanteer. Waar Totius in die felste terme sy vyandigheid teen die kritiese wetenskap uitdruk, word die metodes en resultate daarvan hier genivelleer en/of geïgnoreer. Met ander woorde, die Verklarende Bybel bied volkome onderdak aan die fundamentalisme waardeur hy ongestoort sy gang kan gaan. Billikheidshalwe moet ek vermeld dat prof. Oberholzer my meegedeel het dat daar aanmerklik druk uit Gereformeerde kant uitgeoefen is as gevolg waarvan hy sy oorspronklike inleiding moes oorskryf, hoewel sy basiese sienswyses nie gewysig is nie (mondelinge mededeling 26 Januarie 1978). Dit is nou juis interessant. Daar moet dus toegegee word aan fundamentalistiese druk totdat dié tevrede gestel is. Dan verskyn die werk van fundamentaliste en nie-fundamentaliste onder een sambreel en die fundamentalistiese standpunt is bevredig en versterk. P F D Weiss sê in ' $n$ artikel van $1958^{8}$ dat die medewerkers pogings aangewend het "om mekaar te vind deur woorde of sinne te skrap of anders te formuleer, of deur verskillende opvattings sonder kommentaar naas mekaar te stel" ( $p$ 63). Ek meen dat ek aangetoon het dat dit in werklikheid om veel meer gaan as wat Weiss hier laat vermoed. Sy opmerking is belangrik omdat dit ' $n$ erkenning is van die kompromiebeginsel. Maar wat hy nalaat om te sê, is dat hierdie kompromie uitgeloop het op 'n eindproduk wat as geheel alleen een teologiese tradisie bevoordeel. Vergelyk ons nou die voorwoord, word hierdie beeld bevestig. Die bedoeling van die uitgawe is om sowel behoudend as wetenskaplik te wees. Niks "wat wetenskaplik nie vasstaan nie" mog in die aantekeninge gebied word nie $e^{9}$. In werklikheid word in die aantekeninge nie alleen talle dinge gesê wat wetenskaplik wankelbaar is nie, maar ook wat wetenskaplik onhoudbaar is. "Behoudend" beteken in die lig van die aantekeninge nie bloot teologies behoudend nie, maar dit beteken dat vrae oor outeurskap, datering en historiese juistheid só 
gehanteer word dat 'n fundamentalis dit kan onderskryf. "Wetenskaplik" beteken in dieselfde lig dat die "line of retreat" nog oop bly en dat teenoor die nie-fundamentalis tegelykertyd volgehou kan word dat hier van fundamentalisme geen sprake is nie.

'n Ander invloedryke bron vir ons onderwerp is die radioprogram "Wat sê die Bybel". In 1972 staan prof W C van Wyk in vir een van die gereelde paneellede. Aan hom word die klassieke vraag oor die outeurskap van die Pentateuch gevra. In sy antwoord meld hy dat geleerdes argumente genoem het waarom Moses nie die skrywer kan wees nie, maar dat daar ook ' $n$ ander kant is. Dan verwys hy, soos die fundamentaliste, na die tekste waar van Moses se skryfwerk gepraat word, en dié hou hy dan as 'n versigtige moontlikheid aan die luisteraars voor. Hulle moet die tipiese "Skrifgetuienis"-argument dadelik herken en die fundamentalis is tevrede. So doen hy dieselfde as wat byvoorbeeld Du Plessis en Verhoef in die Verklarende Bybel doen. Ek weet dat professor van Wyk totaal van dié twee verskil, maar in die openbaar het hy dieselfde impak as hulle gehad en dieselfde versterking aan die fundamentalistiese posisie gebied. Die dag ná die uitsending het hy aan my gesê dat hy die vorige aand 'n vertekende beeld van sy eie oortuiging gegee het, maar dat hy nie vir iets anders kans gesien het nie.

Ek het ' $n$ hele aantal ander voorbeelde uit die gepubliseerde weergawe van die radioprogram versame ${ }^{10}$. Ter wille van ruimte kan ek net 'n paar kortliks noem. A $H$ van $Z y l$ gee aan die leser te kenne dat die son volgens Jos. 10 werklik stilgestaan het (of dat die aarde stilgestaan het) - terwyl selfs die opperste fundamentaliste van vandag die astronomiese katastrofe daarvan insien en deur hul tegniek van nieletterlike interpretasie wegverklaar ${ }^{11}$ (Vergelyk I, pp 101-104). H S Pelser "bewys" dat Noag se ark groot genoeg was om al die diersoorte van die aarde te akkommodeer. Dieselfde fundamentaliste na wie pas verwys is, het alreeds hierdie ouer (letterlike) vorm van die fundamentalisme op dié punt prysgegee (llamas, kangaroes en ysbere sou betyds Mesopotamië toe moes reis, probleme met voedselvoorsiening en misverwydering) en deur die pasgenoemde tegniek wegverklaar ${ }^{12}$ (Vergelyk I, pp 104-105). B J Engelbrecht lei die leser om die historisiteit van Samuel se spook te glo en verklaar dan die teologiese probleem van Saul (wat hy sonder meer en ten onregte as 'n ongelowige bestempel) en Samuel (wat volgens hom teenoor Saul 'n gelowige is) in dieselfde doderyk weg deur eenvoudig te sê dit is nie so nie. Hier word die betekenis van die historiese kritiek vir die vraag na dood en onderwêreld eenvoudig geïgnoreer (I, Pp 135-136). In II, pp 28-29 gaan hy prakties net soos Dreyer met die boek Jona te werk. Hy dateer die man Jona selfs in $745 \mathrm{v}$ C. Hy sê Nahum 3 en Sefanja 2 (waar Nineve die oordeel aangesê word) is reg, wat beteken dat die Nineviete weer moes verval het na hul en-masse- 
bekering op Jona se prediking. Ook hier word die literêre oordeel oor die boek Jona geïgnoreer en 'n skynbaar historiese spanning (wat volgens die kritiese wetenskap nooit bestaan het nie) eers gekonstrueer en dan wegverklaar deur 'n onwetenskaplike veronderstelling wat alleen kan werk op basis van 'n ander veronderstelling, naamlik die fundamentalistiese idee dat twee Bybelgedeeltes mekaar nie kan weerspreek nie. In II, pp 63-64 oorweeg Pelser ernstig-naief hoe die aardrykskunde van die wêreld voor die sondvloed daar uitgesien het, asof dit ter sake is. ${ }^{13}$ In al hierdie gevalle word ò fundamentalistiese òf genivelleerde verklarings gegee wat heel natuurlik deur fundamentaliste opgevat sal word as ondersteuning van hul sienswyses.

Vervolgens let ons op 'n paar publikasies wat in die hande van Bybelkunde- en teologiese studente gegee word. $\mathrm{J} \mathrm{H} \mathrm{Kroeze}{ }^{14}$ sê dat Gods openbaring in die skeppingsverhaal nie ' $n$ "wetenskaplike verhandeling" is nie en dat dit nie elke keer op die Procrustusbed van wetenskaplike ontdekkings geplaas moet word om die twee te rym nie. Maar dan wys hy die evolusieteorie af omdat dit in stryd met hierdie openbaring sou wees. As die wetenskap dus sê wat hy wel met sy oortuiging betreffende Gen. $1 \mathrm{kan} \mathrm{rym}$, is dit in orde, anders nie. Wat is dan die sin daarvan om harmonieseringspogings te kritiseer? Veel konsekwenter is $S$ du Toit ${ }^{15}$ wat wel probeer om die natuurwetenskap met Genesis 1 te rym. In reëlregte teenspraak van sy vader meen hy dat die skeppingsdae lang tydperke geduur het omdat die wetenskap dit bewys het. Soos tipies van die hedendaagse fundamentalisme, verwerp Du Toit hier die letterlike interpretasie in die lig van oorweldigende wetenskaplike getuienis. Anders is daar 'n fout in die Bybel, en dit kan nie wees nie. Maar Kroeze is inkonsekwent met sy Procrustusbed. By die geslagsregisters van Gen. ${ }^{16}$, nog 'n konsentrasiepunt van fundamentalistiese skerpsinnigheid, kom hy in die moeilikheid ${ }^{17}$. Volgens die jaartalle in die register is die mensdom vandag 6000 jaar oud, wat veels te min is om met die wetenskap te rym. Daarom kan die register nie bedoel wat sy natuurlike semantiese kwaliteit te kenne gee nie. $X$ kan nie die seun van $Y$ wees nie, maar moet noodwendig "een of ander nakomeling van $Y$ " wees. So is daar dus baie "gapings" in die lys en ons bekom "baie eeue tydwins", waardeur ons die historiese korrektheid van al die gegewens kan handhaaf. Nou word die geslagsregister op 'n Procrustusbed geplaas om tot 'n lang, dun strepie uitgerek te word.

$K^{K r o e z e}{ }^{18}$ se naïwiteit oor die sprekende slang van Genesis 3 is verstommend. Kragtens die getuienis van Bileam se donkie is God in staat om diere te laat praat, en dus kan Hy ook "aan iemand anders toestaan om 'n dier te laat praat". Hier laat God die Satan toe om 'n dier te laat praat. Hoe weet ons dit? - Die uitsprake van die slang "is dinge wat ver uitgaan bo die lewensfeer van 'n dier, hoe skrander 
ook". Verdere kommentaar is oorbodig. In sy Het Boek Jozua, COT, Kampen 1968, stel hy die kritiese bronnesplitsingsteorie belaglik voor sonder om dit te weerle $\hat{e}^{19}$. Hy as eerbiedige Gereformeerde kan dit nie aanvaar nie, en dit is genoeg rede.

Die boek van J G van Niekerk, Openbaringsgeskiedenis - ' $n$ Handle $i-$ ding vir Bybelstudente, Johannesburg* 1976, is van die ergste lektuur wat ek nog teengekom het. Alles in die Ou Testament is voorspellings, voorafskaduwings en tipes van Christus (byvoorbeeld Josef, Josua, Jeremia, Jona, Serubbabel). Die woord Elohim wys op die Drie-eenheid, die wysheid van Spreuke 8 en 9 is die Tweede Persoon van die Drie-eenheid, die mal'ak yhwh is Christus. Evolusie word natuurlik afgewys. 'n Tabel met historiese "prototipes", voorafskaduwings en ' $n$ heilige lyn word verskaf. Die Bybelkundestudent kry geen idee van die literêre karakter van die Bybel en die implikasies van sy historiese onlysting nie. Die detail van die geskrif is benede weerlegging, en ek verwys alleen na die boek omdat dit ontstellend is om te dink dat so iets onderwysers moet vorm aan wie ons kinders toevertrou word. (Ek het reeds die uitwerking van hierdie boek in ten minste een skool waargeneem.)

In die reeks Boeke vir Godsdiensonderrig en Bybelkunde op Skool, opgestel in opdrag van die Interkerklike Komitee vir Onderwys en Opvoeding, kom daar, soos in die Verklarende Bybel, verskillende klemtone voor. Hier sal ek net 'n paar voorbeelde noem omdat my punt in gesprekke met drie Hervormde medewerkers reeds genoegsaam geillustreer word. Prof W C van Wyk het my meegedeel dat hy in sy werk geïnhibeer is deur die wete dat hy bepaalde Afrikaanse kringe moes tevrede stel. Op navraag het hy bevestig dat hy daarmee fundamentalisties-georiënteerde gereformeerde kringe bedoel. Volgens hom was die sogenaamde vryheid wat medewerkers toegelaat is, nie baie funksioneel nie en moes hy bepaalde probleme verbygaan of vaer stel as wat hy sou wou om nie die fundamentalistiese mening te vervreem nie (mededeling 23 Januarie 1978). Proffessore J P Oberholzer (26 Januarie 1978) en J I de Wet (23 Januarie 1978) het dié mening onderskryf. Daarom is dit ook nie verbasend dat professor de Wet se bydrae in Bybelkunde vir St. 9 en 10, Pretoria-Potchefstroom-Kaapstad 1969, dieselfde effek het as wat ek hierbo aangetoon het nie. Hy hanteer die outeurskapsvraag oor die Pentateuch só dat iemand wat in die sfeer van die Totiaanse fundamentalisme tuis is, tevrede sal wees dat Moses tòg die basis geskryf het en dat daar later byvoegings gekom het. Sy bespreking bied ook geleentheid aan die fundamentalis om dit te interpreteer as die "Skrifgetuienis"-beroep waarop Totius en sy geesgenote oor die wêreld heen soveel klem lê. Daarby laat prof. de Wet die "line of retreat" oop sodat hy nie van gewone fundamentalisme beskuldig kan word nie ${ }^{20}$. Dieselfde geld vir sy betoog dat daar nie weersprekings in die Ou Tes- 
tament voorkom nie, wat wel dikwels die geval is (vgl. p 25). Dieselfde effek word nogeens bereik deur Geloofsleer en Sedeleer vir Standerd 10, Pretoria-Potchefstroom-Kaapstad s.j. ( \pm 1965$)$. S J van der Walt skryf (pp 30-31) dat die Bybel "in al sy dele onfeilbaar" is en omskryf dit dan in terme van die fundamentalisme. Nie net die sedelike en godsdienstige boodskap nie, maar ook wat hy die "vorm" daarvan noem. Hy beroep hom op die geliefde fundamentalistiese basis dat Jesus en die Nuwe Testament "ook die geskiedverhale van die Ou Testament as waar en seker aanvaar het". Daarom is ook Genesis 1-11 gewone geskiedenis (waardeur natuurlik Van der Walt se idee van wat geskiedenis is, aan die Ou Testament opgedring word). Verder sê hy, soos Totius, dat die Bybel wel nie 'n handboek vir wetenskap is nie, maar dat "alle gegewens" daarin tog onfeilbaar gesag dra en dat die wetenskap dus "in die lig daarvan" beoefen moet word. Dus tòg maar 'n handboek - of ten minste 'n handleiding - vir die wetenskap. B J Engelbrecht se bydrae in dieselfde boek gaan oor die Wet van God. Dit val op die terrein van hierdie artikel sover as wat hy die indruk skep dat hy met 'n uitleg van die Bybelse vorm van die Tien Gebooie besig is. Hy verwys gedurig in sy bespreking dáárvan na ander Ou-Testamentiese passasies buite hulle konteks en laat sy leser dus onder die indruk dat die Ou-Testamentiese teks van die Tien Gebooie alles sê wat hy as etikus na áánleiding daarvan sê. So word daar in die hande van 'n wesenlik a-historiese fundamentalisme gespeel.

Nou kom 'n volgende verskynsel aan die beurt. Barr' ${ }^{21}$ het aangetoon hoe daar onder diegene wat wantrouig staan teenoor die kritiese Bybelwetenskap 'n groot belangstelling ontstaan het vir die randgebiede van die Bybelwetenskap (Zeitgeschichte, kultuurgeskiedenis, argeologie). In ironiese kontras teenoor die liberalisme van die eeuwisseling, toe hierdie gebiede juis vir die teenoorgestelde doel gebruik is, word daar nou besonderlik hierop gekonsentreer om die tradisioneel gereformeerde standpunt toe te lig, te onderbou en te verdedig. Die leidende en invloedrykste figuur in hierdie opsig is F C Fensham. Hy is baie goed ingelig, maar die aanwending van sy kennis moet bevraagteken word. 'n Uitstekende bron om sy metode te analiseer, is sy boek Wetenskap en Bybelkunde, Kaapstad 1964. Op pp 39-41 betoog hy dat die Israeliete nie deur die Rooi See nie, maar deur 'n rietmeer in die Nyldelta getrek het. Daar waai die wind so sterk "dat dit die water in 'n bepaalde rigting dwing". Hy verklaar met 'n rasionalistiese gebruik van natuurwetenskaplike gegewens hoe die Israeliete droogvoets kon deurtrek - wat tipies is van die negentiende eeuse liberalisme. Glad nie, verseker Fensham ons. Die wind het begin waai net mooi toe Israel by die water aangekom het. En "dit toon aan dat ons hier met die direkte bemoeiing van God te doen het. Dit was dus 'n wonder wat plaasgevind het". Net op die- 
volgende bladsy spring Fensham met 180 grade om. Die teorie bestaan dat die Israeliete die wolke (waarskynlik rookwolke) van die vulkaan al-Hrob aangesien het vir die wolkkolom wat hulle bedags so beïndruk het, en die vulkaniese uitbarsting van die nag vir die bekende vuurkolom. Nee, sê Fensham, dit kan nie uit 'n Skrifgelowige oogpunt (Totius se terminologie) aanvaar word nie, want dan bly niks van die wonder oor nie en so val die verbond plat en boonop die hoeksteen van ons hele geloof. Waarom kon, kragtens Fensham se eie logika van die vorige bladsy, die vulkaan nie as teken van Gods direkte bemoeiing net mooi by Israel se aantog tot uitbarsting gekom het nie? Fensham poog graag om "die betroubare tradisie van die Skrif" ( $p$ 30) te bevestig. Hy sê nooit dat die argeologie die geloofwaardigheid van die Bybel berwys nie, maar sy hele aanpak en redenasielyn het dieselfde effek (soos ook by $S$ du Toit en 'n keer by Totius self). Nadat hy byvoorbeeld die skeptisisme van Albrecht Alt en Martin Noth oor die belang van die historiese Moses afgewys het, sê hy dat sy eie standpunt is om vir geen oomblik "die betroubare tradisie van die Skrif" in twyfel te trek nie (weer die idee van historiese "betroubaarheid" wat gelykgestel word aan teologiese of geloofsbetroubaarheid"2. Hy voeg by: "In die verlede het die argeologiese wetenskap deur sy resultate telkens bewys dat dinge wat deur geleerdes in hul ivoortorings beweer word, geheel en al uit voeling met die werklikheid is". Nou kan daar wel deeglik wetenskaplike beswaar ingebring word teen ' $n$ minimalisering van Moses se historiese rol. Maar nie op Fensham se manier nie. Hy formuleer só dat hy sy "intellectual respectability" behou, maar die leser kan sy woorde nie anders lees as 'n verdediging van die Bybel teen die aanvalle van geleerdes nie. Die fundamentalis is tevrede dat "die glorie van die Bybel" deur die oudoosterse geleerdheid gehandhaaf is ${ }^{23}$. So funksioneer Fensham se hele boek. Presies dieselfde effek het $\mathrm{S}$ du Toit se boek $\mathrm{Ou}$ Testament en Ou Ooste, Potchefstroom 1971. Hy wil nie die Bybel korrek bewys nie, want die geloofwaardigheid van die Bybel is nie van bewyse afhanklik nie. Maar die hele opset van sy boek is bedoel om aan te toon dat die argeologiese wetenskap ons daartoe bring om die andersheid van die Ou Testament "slegs aan openbaring" toe te skryf ${ }^{24}$.

Die werk van P A Verhoef adem 'n ander gees. Anders as Kroeze en $\mathrm{Du}$ Toit, by wie daar besliste fundamentalistiese trekke is, werk hy op 'n gereformeerde standpunt sonder om dispute oor die tradisionele strydpunte met die kritiese wetenskap op die spits te dryf. Waar dit nie anders kan nie, nivelleer hy ook sulke probleme (sien hierbo oor die Verklarende Bybel). In sy Metodiek van die eksegese, Kaapstad 1973 reken hy met kritiese, gereformeerde en Roomse geleerdes. Hy stel egter met klem die kritiese werke teenoor gereformeerde werke. Hy handhaaf versigtig die onderskeid tussen "kri- 
ties" en "gereformeerd" (asof daar 'n teenstelling behóórt te bestaan). Hy is wel gewillig om van die kritici oor te neem wat binne sy gereformeerde raamwerk sou pas. 'n Goeie 1972 te vinde. Hy verwerp die standpunt dat die profete deur die historiese horison van hul tyd begrens was - wat weer deur kritici volgehou word. Die rede hiervoor is nie Ou-Testamenties verantwoord nie, maar dogmaties, naamlik dat God sy woord vir alle tye bestem het ( $p 16)$. Die beperkings wat dit op die analise van die profeteboeke plaas en die hermeneutiese konsekwensies daarvan word nie deur hom in berekening gebring nie. Weer eens is dit 'n standpunt wat, sonder om fundamentalisties in enge sin te wees, die fundamentalisme akkommodeer. Ook A H van Zyl se boek Gods Woord in Mensetaal, Durban ${ }^{2}$ 1975, moet hiermee saam genoem word. Hierin toon Van Zyl duidelik sy openheid vir die kritiese wetenskap, maar sy eindproduk is volledig aanvaarbaar vir die fundamentalis wat nie bereid is om die moderne Bybelwetenskap te aanvaar nie.

In die lig van hierdie oorsig kan ons drie kategorieë onderskei: (1) Volledige fundamentaliste. (2) Diegene wat hulle nòg teen die fundamentalisme nòg teen die kritiese wetenskap uitspreek, maar wie se werk laasgenoemde wantrou en eersgenoemde voed. (3) Diegene wat prinsipieel die fundamentalisme afwys, maar nogtans bereid is om só te skryf dat die oogmerke en tegnieke van die fundamentalisme oogluikend gedien word. Die fundamentalisme in ons land word nooit effektief bestry nie.

\section{III}

Ons kan verwag dat die prediking uit die Ou Testament in hierdie situasie daaronder sal ly. Dit is na my waarneming ook in al drie die Afrikaanse kerke die geval (waaroor ek elders iets meer gesê het). Die verklaring hiervoor is eerstens die bereidheid om die grondliggende uitgangspunte van die fundamentalisme tegemoet te kom - soos ek hierbo betoog het. Die konklusie lyk my onontkombaar dat daar binne die derde kategorie wat ek genoem het, 'n werklike verskil bestaan tussen wat in die akademiese kring geglo word en wat by wyse van populêre publikasie die wêreld ingestuur word. ' $n$ Tweede verklaring vir die deurwerking van die gesketsde situasie op die prediking is waarskynlik die invloed van die huidige Afrikaanse Bybelvertaling wat grootliks Totius se stempel dra. Veral die gebruik van hoofletters by voornaamwoorde en substantiewe wat in die bekende fundamentalistiese interpretasie na Christus sou verwys (byvoorbeeld sekere koningspsalms soos Psalms 2 en 45, maar nie Psalms 21 en 72 nie) moet hier genoem word. Verder ook die vertaling van beroemde (of berugte!) passasies soos Jesaja 7:14, die opskrifte by die perikope, sowel as kruisverwysings in die Naslaanbybel. Hierdie 
dinge veronderstel ' $n$ ganse teologiese en hermeneutiese onderbou wat die hele wese van die verstaan van die Ou Testament ten diepste raak, en wat òf fundamentalisties is ò simpatiek teenoor die fundamentalisme staan.

Ek is oortuig daarvan dat die fundamentalisme die handhawing van die ortodokse belydenis en die reformatoriese tradisie in die weg staan. Hier kan ons Berkouwer ${ }^{25}$ volg wanneer hy van die kritiese wetenskap sê: “... wel is de weg van het serieuze bijbelonderzoek onvermijdelijk, juist uit respect voor het gezag der Schrift". Dit stel hy (pp 11-12) teenoor die fundamentalisme wat, vanweë sy (ongegronde) angs vir die wetenskaplike ondersoek, wel nie die klank van menslike stemme in die Bybel kan ontken nie "maar (men) schenkt er weinig aandacht aan". Hierdie erkenning gepaard met ignorering is juis wat ek hierbo probeer aandui het. Die moderne kritiese wetenskap ondergrawe nie die belydenis nie, maar gee aan die eksegeet die geleentheid om die ryke prediking van die Bybel in sy nuanses en skakeringe te ontdek en met beskeie versigtigheid vir die prediking vrugbaar te maak. Illustrasies hiervan het ek elders gebied, sodat dit nou nie weer nodig is nie. Hierdie rykdom is by voorbaat deur die fundamentalisme verbeur omdat hy vanweë sy verstrakking en verstrikking in ' $n$ aantal "fundamentals" ${ }^{26}$ die weg daarheen afsny in die ongegronde vrees dat die belydenis daardeur in gevaar kom. Dit is ironies dat die groepe wat juis die grootste bedreiging vir die reformatoriese belydenis inhou, self fundamentalisties werk (byvoorbeeld pinkstersektes en ander heterodokse groepe). Ek mag hier byvoeg dat ek dink dit is prakties moontlik om die resultate van die kritiese wetenskap (nie die wetenskaplike proses self nie) in die prediking vrugbaar te maak - sonder dat dit ontsteltenis by ouer lidmate veroorsaak. So kan tegelykertyd die probleme wat veral onder die jonger geslag opkom (sien hieronder), bevredigend beantwoord word èn daarin geslaag word om nie die sekerheid van ander lidmate aan te tas nie. Hierdie stelling is gegrond op oor ' $n$ honderd proefnemings wat ek gedoen het in gemeentes van die mees uiteenlopende aard. Selfs nie eers teenwoordige predikante het teenoor my opgemerk dat hulle die afwysing van 'n fundamentalistiese eksegese opvallend of steurend gevind het nie. (Vier van hierdie preke is in die NG-kerk gehou en twee was gesamentlike dienste van lidmate uit die drie Afrikaanse kerke.)

Hierby kom die vraag na vore of ons die waarheid in die teologie kan dien deur die onwaarheid of deur die onwaarheid te gedoog. Kan ons toelaat dat mense verkeerde dinge glo en andere verkeerde dinge leer alleen sodat fundamentaliste nie gefrustreer moet word nie? Hier wil ek my ondersteuning uitdruk vir die grondtese van $C J$ Labuschagne se boek Wat zegt de bijbel in Gods naam, 's-Gravenhage 1977. Hoewel ek dit nie eens is met baie van die detail in sy boek nie, 
is sy basiese betoog myns insiens van die uiterste belang. Die regte verstaan van die Bybel en die ontsluiting van sy veelkleurigheid en krag vir ons wêreld kan alleen gedoen word deur voluit erns te maak met die resultate van die kritiese wetenskap. Dit beteken om dié te laat deurwerk "tot op het grondvlak van de kerk" en nie om dit gedeeltelik ernstig te neem in die beperkte kring van vakspesialiste terwyl "het grondvlak van de kerk" daarteen "beskerm" word nie.

Hier kom die vraag na die onderwys en ons samewerking met die ander twee kerke in gemeenskaplike projekte ter sprake. Dit is vir my 'n bron van groot kommer dat die fundamentalisme deur die onderwys versterk en versprei word. Daarvan getuig die handboeke vir onderwysstudente en onderwysers wat ek genoem het. Die fundamentalisme kan nie die vrae beantwoord wat die jeug van vandag en die moderne wêreld oor die algemeen vra nie. Vrae oor die verstaan van die Bybel in die moderne wêreld, byvoorbeeld evolusie, weersprekings in die Bybel, en selfs gesofistikeerde vrae oor historiese probleme en die literêre aard van die Bybel, kom al hoe meer op. Dit word nie deur 'n simplistiese fundamentalisme beantwoord nie - nòg in werklikheid nòg tot die bevrediging van die vraers. Vanlaasgenoemde is ek oortuig deur gesprekke met mediese studente, studente in die fisika en biologie, jong rekenaarwetenskaplikes, en les bes ook Bybelkundestudente. Selfs skoolkinders is sinies oor dit wat byvoorbeeld vir hulle uit J G van Niekerk se aangehaalde boek opgedis word. Ek dink dat ons te doen het met die eerste tekens van wat in Europa ingetree het. Die jeug het vrae gestel wat die dominee nie kon beatwoord nie. Goeie voorbeelde word gegee deur C A de Leeuw, Kinderen van de rekening. Christelijk onderwijs: een taak voor ouders en docenten, Kampen $17 / 1975^{27}$. As hulle nie' $n$ ander antwoord kry nie, werk dit vervreemdend. En as hulle alles gelate aanvaar, is dit nog erger, want dan dring die fundamentalisme net dieper in om noodwendig een of ander tyd 'n ernstige konsekwensie te hê. Hier kan ons leer van wat reeds in Nederland gebeur het. Omdat predikante nie die moed, die vermoë of die bereidwilligheid gehad het "de gemeenteleden te informeren over de bona fide resultaten van wetenschappelijk bijbelonderzoek ..." het "een vertrouwenscrisis die vrijwel onoplosbaar is", ingetree ${ }^{28}$. Ons kan ons nog betyds gereedmaak om so 'n grootskaalse vertrouenskrisis te voorkom.

Samewerking met fundamentaliste aan gemeenskaplike projekte van hierdie aard is vir my' $n$ ekumeniese probleem. Prof $C \mathrm{H}$ Rautenbach skryf in Die Hervormer van Maart 1978 (p 24) dat verskeidenheid ook 'n sondige kant het "wat geneë maak om alleenreg vir eie benadering op te eis en nie dieselfde aan die ander te gun nie". Is dit nie óók waar van die eenheidstrewe op die huidige Afrikaanse kerklike toneel nie? As ek reg waargeneem het, kom so 'n onverdraagsaamheid wel voor, naamlik op'n subtiele wyse wat dit onmoontlik maak 
dat die konsekwensies van die prinsipiële Hervormde standpunt oor die gebruik van die Bybel in die praktyk tot hul reg kom. Dàt ons met mekaar moet saamwerk, ly geen twyfel nie. Maar wat as samewerking altyd beteken dat die kritiese wetenskap gedurig moet toegee? Kan ons werklik probleme uit die weg loop of vervaag teen hierdie prys? Vir my lyk dit onmoontlik. Die enigste oplossing wat ek kan sien, is dat 'n werkverbond opgerig moet word tussen fundamentaliste, semi-fundamentaliste en kritiese teoloë. Almal sal mekaar se standpunte moet respekteer en mekaar toelaat om na werklike oortuiging te skryf. Daar sal natuurlik groot teenstand wees, maar dit gaan my nou alleen om die soeke na 'n eerlike basis vir samewerking. Verwarring by leerlinge en hul leermeesters as gevolg daarvan, sal nie méér skadelik wees as wat tans die geval is nie. En uiteindelik móét die onverantwoordbare voor die verantwoordbare swig. Verskillende menings naas mekaar is gesond, want dit dwing tot ' $n$ selfstandige keuse en kweek daarom 'n goeie kritiese sin.

Ten slotte: Ons sal moet erken dat, ten spyte van die tradisionele Hervormde standpunt wat anti-fundamentalisties is, die nawerking van die fundamentalisme van die Totius-model nog in ons Afrikaanse huishouding bestaan. Ons sal, om hierdie ban te deurbreek, ons teoretiese anti-fundamentalisme moet omskakel in 'n positiewe optrede "tot op het grondvlak van de kerk". Dit sal 'n wins vir die kerk van Christus wees.

\section{VERWYSINGS}

1. Fundamentalism, Londen 1977

2. Op. cit., pp 123-126

3. Vergelyk J V Coetzee in P J Nienaber ed., Totius - Digter en Profeet, Johannesburg 1948, p 55

4. Vergelyk Barr, op. cit., pp 94-97

5. Vergelyk Barr, op. cit., pp 128-131, 135

6. "Vyftig jaar byderwetse Bybelwetenskap", in Versamelde Geskrifte, Kaapstad 1975, pp 456-474 (p 461)

7. Die smagting na "intellectual respectability" waarvan Barr, op. cit., p 125, praat.

8. "Die 'Seuns van God' in Genesis 6:1-4", HTS 14 (1959), pp 53-67

9. Vergelyk weer wat Barr noem "crave intellectual respectability", op. cit., p 125

10. Wat sê die Bybel, saamgestel deur Danie Erasmus, Pretoria 1970 vir Deel I en 1972 vir Deel II.

11. Vergelyk Barr, op. cit., pp 244-245

12. Vergelyk op. cit., pp 94-95.

13. Vergelyk virder ook I, pp 40-43, 58-60, 105-106, 107-109, 126-127, 144-145, 145146, 153-154; II, pp 19, 38-40, 42-43, 163-164, 164-166.

14. Handboek Bybelse Geskiedenis - Die Ou Testament, Pretoria-Potchefstroom-Kaapstad 1965, pp 37-38.

15. "Divine Revelation in Holy Schripture", in De fructu oris sui, Leiden 1971, pp 181-200, vergelyk p 197.

16. Op. cit., pp 56-58.

17. Vergelyk ook Van Zyl in Wat sê die Bybel I, pp 136-137

18. Op. cit., p 44 . 
19. Vergelyk veral $p p 13,23$

20. Op. cit., pp 17-23.

21. Op. cit., pp 128ff.

22. G C Berkouwer, "Het Schriftgezag" in G C Berkouwer en A S van der Woude ed., De bijbel in het geding, p 13: Die mense het dikwels in die Bybel 'n bron van gesag gesien "op allerlei terrein van de wetenschap"; vergelyk ook $R$ Bijlsma, Het oude boek en de nieuwe mens. De Bijbel: cultuurdocument en geloofsboek, Baarn 1972.

23. Net soos Totius, op. cit. IV, pp 312-315.

24. Vergelyk die voorwoord, $\mathrm{p} 7$.

25. Op. cit., p 13.

26. Barr, op. cit., p 2.

27. Vergelyk veral die laaste hoofstuk, pp 75ff. Vergelyk ook J K Coetzee, Godsdienstige meelewing en betrokkenheid van lidmate van die NG Kerk in Transvaal, diss. UP 1973: $40 \%$ + van die lidmate twyfel aan die betroubaarheid van die Bybelse beginsels. Van jongmense tussen 16 en 24 jaar twyfel $50 \%+$ aan die betroubaarheid van die Bybel (pp 176-177). Van die groep tussen 16 en 34 jaar twyfel 30\%+ of hulle godsdienstig genoem wil word (pp 64-65.)

28. J M de Jong, "Schriftgezag en wetenschap", in G C Berkouwer en A S van der Woude ed., De bijbel in het geding, Nijkerk 1968, pp 129-144- hier p 131. 